\title{
Evaluasi Pembelajaran Mata Kuliah Audit Pada Mahasiswa Politeknik Negeri Bengkalis
}

\author{
Suharyono \\ D4 Akuntansi Keuangan Publik Politeknik Negeri Bengkalis \\ Email: suharyono@polbeng.ac.id
}

(Received: 22 November 2020; Accepted: 24 Desember 2020; Published: 13 Januari 2021)

\begin{abstract}
This study aims to compare learning outcomes or student competencies and treatment methods in audit courses for one semester. All students who have taken the audit course with a total of 52 people are made into the population in the study to ensure that the results obtained in the study will represent all students without exception. With details of 27 class A students and 25 class B students. Hypothesis testing was performed using the Mann Whitney test, because the research data were not normally distributed with a sig 0 percent value. Based on the SPSS output on the Mann-Whitney nonparametric statistical difference test, the sig result is 34.8 percent. The sig number of 34.8 percent is certainly more generous than the alpha value of 5 percent. Thus, it is clear that based on the evaluation of the learning outcomes of the audit course between class A and class B students of the Bengkalis State Polytechnic Public Financial Accounting Study Program, there is no difference. The teaching methods that have been applied in the lecture process have improved students 'skills and knowledge in the field of audit, both in class A and in class B. A fair lecture process or knowledge transfer, even though it is in a different class, will impact increasing students' knowledge and competence in auditing a company's financial statements.
\end{abstract}

Keywords: Learning Evaluation; Student Competence; Financial statements; Audit

\begin{abstract}
Abstrak
Penelitian ini memiliki tujuan untuk membandingkan hasil belajar atau kompetensi mahasiswa dan metode pengajaran pada mata kuliah audit selama satu semester. Seluruh mahasiswa yang telah mengambil mata kuliah audit dengan total 52 orang dijadikan populasi dalam penelitian, dengan rincian 27 orang mahasiswa kelas A dan 25 orang mahasiswa kelas B. Uji hipotesis dilakukan dengan menggunakan uji Mann Whitney, karena data penelitian tidak terdistribusi normal dengan nilai sig 0 persen. Berdasarkan output SPSS atas uji beda statistik nonparametrik Mann Whitney diperoleh hasil sig sebesar 34,8 persen. Berdasarkan evaluasi hasil belajar mata kuliah audit antara kelas A dan kelas B mahasiswa Prodi D4 Akuntansi Keuangan Publik Politeknik Negeri Bengkalis, tidak ditemukan adanya perbedaan. Metode pengajaran yang telah diterapkan dalam proses perkuliahan telah meningkatkan kemampuan dan keilmuan mahasiswa di bidang audit baik di kelas A maupun di kelas B. Setelah dilakukan evaluasi atas nilai akhir mahasiswa, hasil penelitian tidak menemukan perbedaan signifikan. Proses perkuliahan atau transfer ilmu yang baik meskipun di kelas yang berbeda, akan berdampak bagi peningkatan ilmu dan kompetensi mahasiswa dalam mengaudit laporan keuangan sebuah perusahaan.
\end{abstract}

Kata Kunci: Evaluasi Pembelajaran; Kompetensi Mahasiswa; Laporan Keuangan; Audit

\section{PENDAHULUAN}

Di dunia kerja, salah satu peluang yang menjamin masa depan adalah berprofesi sebagai auditor. Proses transfer pengetahuan dalam mata kuliah audit yang menjadi salah satu dasar yang membentuk kompetensi seorang auditor membutuhkan kombinasi perspektif ilmu yang begitu luas. Hakikatnya, berprofesi sebagai auditor yang kompeten tidak hanya didukung 
oleh kemampuan dan pemahaman akuntansi secara kognisi semata, tetapi haruslah didukung dengan kemampuan soft skill, meliputi: ketelitian, kecerdasan, kejujuran, kedisiplinan, dan bertanggungjawab.

Mahasiswa jurusan akuntansi selama di bangku kuliah telah mendapatkan transfer ilmu dan kompetensi di bidang audit. Audit termasuk kompetensi utama dalam Standard Kompetensi Kerja Nasional Indonesia (SKKNI) yaitu menjalankan proses di bidang audit yang berkaitan dengan informasi keuangan. Mahasiswa yang mengambil jurusan akuntansi dituntut untuk memperdalam analisa terkait kasus-kasus kecurangan yang terus saja ditemukan dan terungkap. Mahasiswa yang telah mempelajari mata kuliah audit diharapkan memiliki kemampuan untuk mendapatkan informasi terkait audit. Menurut Sahade (2020) kenaikan hasil prestasi belajar didominasi oleh kemandirian belajar.

Sebagai auditor tentunya memiliki tanggung jawab yang besar untuk menjamin bahwa pekerjaan audit atau pemeriksaan yang dilakukan pada laporan keuangan sebuah perusahaan telah dilakukan dengan independen. Pelaksanaan audit yang menyeluruh sesuai dengan ketentuan yang ditetapkan akan menghasilkan opini audit untuk menetapkan kewajaran atas nominal dalam laporan keuangan. Auditor memiliki kewajiban untuk menjalankan etika profesi sebagai prinsip hidup sesuai dengan ketetapan dari Ikatan Akuntan Indonesia (IAI). Agar menjadi auditor yang profesional, wajib menjalankan kode etik sebagai auditor.

Mempelajari ilmu audit dibutuhkan keseriusan dan fokus. Mulai dari membuat rencana dan metode pemeriksaan, melakukan aktivitas pengujian atas aspek pengendalian dan bukti transaksi, menjalankan prosedural analitis secara rinci atas saldo akun di setiap laporan keuangan, serta menyelasaikan proses pemeriksaan dan penyusunan laporan hasil audit.

Audit mesti direncanakan sebaik mungkin agar dapat memeriksa laporan keuangan suatu perusahaan dengan optimal sehingga dapat menimbulkan rasa yakin bahwa laporan keuangan terhindar dari kesalahan atau salah saji yang material. Selain itu, perencanaan yang optimal dapat memberikan keyakinan tentang pertanggungjawaban manajemen atas aset yang dikelola. Kesalahan penyajian yang dapat berawal dari kesalahan pencatatan atau bahkan kecurangan
Mempelajari audit membantu memberikan pertanggungjawaban yang efektif dan mencegah penyalahgunaan uang di pemerintahan maupun di perusahaan. Mempelajari audit seharusnya memiliki dampak positif bagi mahasiswa, khususnya dalam mempertanggungjawabkan seluruh aktivitas pengelolaan aset. Ini akan memberikan gambaran kepada mahasiswa tentang arti penting kejujuran dan kewajaran khususnya bagi mahasiswa Program Studi D4 Akuntansi Keuangan Publik yang nantinya akan terjun ke dunia usaha atau dunia kerja atau industri.

Menurut Suharyono dan Widodo (2017) mahasiswa akuntansi harus memiliki kompetensi yang mengacu pada SKKNI. Uji Mann-Whitney menjadi pilihan dalam menguji hipotesis penelitian dengan populasi sebanyak 81 mahasiswa. Hasilnya membutikan bahwa prestasi dan kompetensi mahasiswa menggunakan software MYOB di antara ketiga kelas tidak terdapat perbedaan. Meskipun mahasiswa tersebut diajarkan oleh dosen-dosen yang berbeda, namun kompetensi yang dicapai oleh mahasiswa tetap sama. Ini membuktikan bahwa modul yang digunakan dalam perkuliahan mampu menghasilkan mahasiswa yang kompeten dalam mengoperasikan software akuntansi.

Wibowo (2011) mengatakan bahwa proses kuliah auditing berkaitan erat dan tak terlepas dengan kebutuhan di dunia kerja dan dunia praktik. Ilmu audit merupakan dasar kompetensi yang wajib diterapkan kepada orang yang menginginkan berprofesi sebagai auditor. Ilmu audit memiliki perspektif berbagai bidang ilmu yang luas. Hasil penelitian menunjukkan bahwa mempelajari mata kuliah auditing penting sebagai dasar yang menunjang kompetensi audit.

Penelitian Anas (2019) bertujuan untuk menemukan bukti empiris terkait dengan diterapkannya model cooperative learning, case based learning, dan student centered learning terhadap tingkat pengetahuan mahasiswa di pelajaran auditing 1. Dengan total responden sebanyak 17 orang mahasiswa. Data penelitian diuji dan diolah dengan memanfaatkan model uji regresi linier berganda pada $\alpha$ 5persen. Hasil analisis output SPSS menunjukkan bukti empirik bahwa case based learning secara meyakinkan dan signifikan berpengaruh pada peningkatan pemahaman mahasiswa di pembelajaran mata kuliah auditing 1 . Penerapannya memperlihatkan bahwa pengaruhnya tidak begitu signifikan terhadap pemahaman mahasiswa dalam 
mempelajari auditing 1. Implementasi metode pengajaran dalam suatu pembelajaran audit dinilai mampu mengaktualisasikan potensipotensi sosial dan emosional mahasiswa serta dapat meningkatkan kompetensi mahasiswa untuk menjadi calon auditor masa depan.

Penelitian Hawani dan Rahmayani (2016) memiliki tujuan untuk melihat pengaruh pengetahuan mahasiswa berkaitan dengan pajak dan audit pada minat untuk memilih karir di pajak dan audit. Variabelnya minat berkarir sebagai variabel dependent dan pengetahuan mahasiswa di bidang audit dan pajak sebagai variabel independent. Penelitian ini populasinya adalah mahasiswa akuntansi yang lulus mata kuliah perpajakan dan auditing, dengan responden sebanyak 100 orang. Penelitian ini mendapatkan hasil bahwa ilmu pengetahuan yang diperoleh mahasiswa di bidang pajak dan audit signifikan pengaruhnya terhadap kemauan untuk memilih karir sebagai petugas pajak atau sebagai auditor.

Rosnidah et al. (2018) melakukan penelitian eksperiman tentang dilema calon auditor. Menurutnya, dilema tentang etika adalah kondisi yang banyak dijumpai oleh seseorang saat dilibatkan pada korelasi yang ada arah pada fidusia. Di sisi lain, masalah ini selalu dihadapi mereka yang berprofesi sebagai auditor saat menyerahkan jasa profesionalnya yang harus mampu menghindari diri terhadap kepentingan pribadi dan kelompok. Penelitian ini diteruskan pada mahasiswa prodi akuntansi yang telah mengikuti mata kuliah audit dan pengetahuan etis yang akan memilih menjadi auditor potensial. Respondennya adalah para mahasiswa prodi akuntansi tingkat 3 di Fakultas Ekonomi Unswagati. Arah penelitiannya dilakukan dengan kasus yang terkait pada pekerjaan yang mengarah pada berbagai tindakan-tindakan yang bisa saja tindakan tersebut dengan prinsip etika akan bertentangan. Auditor yang harus menerapkan prinsip dan etika dibuat dilema dengan kasus pekerjaan tersebut. Dengan memberikan kasus tersebut pada para mahasiswa, membuat mahasiswa memilih apakah akan melanjutkan tugas yang bertentangan dengan kompetensi mereka dengan batas waktu tertentu atau mahasiswa terpaksa menolak tugas yang diberikan tersebut. Berdasarkan analisis kasus, diperoleh hasil penelitian bahwa bagi mahasiswa akuntansi yang paham tentang etika akan lebih memikirkan dan mempertimbangkan beberapa hal dan menemukan solusi saat mendapatkan tugas yang belum sesuai dengan kompetensi yang ada padanya. Kesimpulannya adalah hasil evaluasi mahasiswa yang telah lulus dan paham dengan auditing akan memiliki etika yang lebih tinggi.

Berdasarkan Satuan Kredit Semester (SKS) mahasiswa harus mampu menyelesaikan mata pelajaran akuntansi sektor publik dengan benar sesuai dengan ketentuan. Hasilnya bahwa pemahaman pembelajaran pada kuliah akuntansi sektor publik lanjutan antara kelas A dan kelas B ditemukan perbedaan. Lingkungan suasana belajar pada mata kuliah akuntansi sektor publik lanjutan di setiap kelas mempengaruhi hasil belajar siswa (Suharyono and Mule; 2019).

Penelitian Jalil (2014) mengkaji anteseden perilaku whistleblowing melalui komitmen profesional dan audit mahasiswa sosialisasi antisipatif. Hal tersebut memperluas hasil penelitian Elias (2006) dan mengkritisi ketidaksesuaian antara hipotesis dengan alat pengujian yang digunakan. Data yang digunakan adalah 104 mahasiswa, dan uji regresi berganda dan uji $t$, digunakan dalam penelitiannya. Hasilnya, komitmen profesional mempengaruhi whistleblowing. Selain itu, tidak ada perbedaan yang signifikan terhadap tingkat sosialisasi antisipasi responden terhadap whistleblowing. Penelitian ini memberikan tambahan literatur audit dengan melakukan uji beda antara komitmen profesional dan juga sosialisasi.

Penelitian Lubis (2018) bertujuan untuk meningkatkan aktivitas dan hasil belajar siswa melalui penerapan pembelajaran berbasis masalah sebagai upaya peningkatan kualitas pembelajaran pada mata kuliah auditing. Metode yang digunakan adalah prosedur penelitian tindakan, dengan teknik pengumpulan data dalam penelitian ini meliputi tes, dokumentasi dan teknik analisis data observasi selanjutnya yang digunakan dalam penelitian ini adalah analisis deskriptif dan analisis kualitatif. Berdasarkan analisis data observasi bahwa aktivitas siswa kelas VI-A Akt Awal dalam perkuliahan Auditing sebesar 51persen dengan kategori kurang baik sedangkan mahasiswa aktif sebesar 18persen hal ini menunjukkan rendahnya aktivitas siswa dalam pembelajaran auditing. Pada siklus II keaktifan siswa 44persen aktif dan 13persen sangat aktif dan kurang aktif 43persen. Hasil ini menandakan bahwa aktivitas siswa pada siklus II meningkat dan akan berhubungan dengan hasil belajar siswa. Hasil belajar siswa pada siklus I yang tuntas hanya sebesar 35,90persen pada siklus II sebesar 
74,36persen artinya terjadi peningkatan hasil belajar pada siklus II dibandingkan pada siklus I yaitu hasil belajar audit siklus II, tetapi hasilnya lebih baik, sehingga dapat disimpulkan bahwa dengan menggunakan metode pembelajaran audit problem based learning dapat diterapkan di kelas karena berdampak bagi peningkatan nilai siswa.

Suharyono (2019) melakukan penelitian tentang penerapan MYOB Clinic, pada mahasiswa. Terdapat 52 responden yang terpilih. Hipotesi penelitian di uji dengan uji regresi berganda. Hasil penelitiannya adalah implementasi MYOB test clinic, telah membuat nilai rata-rata mahasiwa mengalami peningkatan dari 48 menjadi 74 atau 52persen. dipengaruhi oleh variabel-variabel yang lain.

Kamus Besar Bahasa Indonesia (2011) menjelaskan bahwa audit didefinisikan sebagai aktivitas memeriksa bukti-bukti catatan keuangan perusahaan atau menguji efektivitas arus dana masuk dan dana keluar untuk menilai laporan keuangan yang disusun wajar atau sebaliknya. Audit menurut Arens dan Lobbecke (1997) adalah proses mengumpulkan data dan melakukan evaluasi bukti-bukti agar memperoleh informasi yang bisa diukur dan dapat menggambarkan tentang entitas dari segi ekonomi. Audit hanya dapat dijalankan oleh seorang yang berkompeten dan berjiwa independen supaya bisa membuat penentuan dan pelaporan tentang kecocokan informasi dengan standar keuangan yang telah ditetapkan.

Audit memiliki scope yang luas karena berkaitan dengan aspek manajemen, sehingga lingkupnya terdiri atas aspek finansial dan non finansial, yaitu: audit finansial adalah pemeriksaan yang dilakukan dengan berfokus pada permasalahan finansial. Audit ini memiliki sasaran untuk memeriksa kewajaran atas laporan keuangan yang disusun oleh manajemen. Kini, internal auditor orientasinya tidak hanya pada persoalan keuangan semata, tetapi lebih difokuskan pada audit operasional di perusahaan. Pemeriksaan atas bukti-bukti transaksi pada laporan keuangan perusahaan menjadi wewenang Kantor Akuntan Publik (KAP) atau Badan Pemeriksa Keuangan (BPK). Audit operasional disebut juga audit kinerja manajemen. Fokus audit kinerja adalah kesesuaian dengan aspek efisiensi, aspek efektivitas dan aspek ekonomis (3E). Audit kinerja memiliki peranan yang penting untuk mengukur key performance index. Compliance audit disebut juga audit dengan tujuan pengujian sebuah audit yang bertujuan untuk menguji kepatuhan. Auditor akan menilai bagaimana penerapan aturan dalam pelaksanaan kegiatan. Aturan yang menjadi acuan auditor yaitu peraturan perundang-undangan, Standard Operating Prosedure (SOP), dan surat keputusan. Selain itu, perusahaan memiliki sertifikat International Organization for Standardization (ISO) maka compliance audit akan dilakukan oleh auditor khusus ISO demi mempertahankan sertifikat ISO yang diraih perusahaan sebelumnya. Fraud audit yaitu audit khusus yang dilakukan untuk memeriksa besaran kerugian negara akibat kecurangan. Nama lain audit kecurangan adalah audit investigasi. Saat ini, audit kecurangan telah mengalami perkembangan dengan mengembangkan audit mengenai akuntansi forensik (forensic accounting) dalam mengungkap kejahatan keuangan.

Menjadi auditor profesional mesti didukung dengan komitmen profesional agar dapat mengutamakan keprofesionalimenya dalam bekerja dan menjunjung tinggi nilai-nilai etika profesi secara bertanggungjawab. Audit menjadi salah satu unit kompetensi dalam Standar Kompetensi Kerja Nasional Indonesia (SKKNI) yaitu menjalankan suatu proses di bidang audit yang berkaitan dengan informasi keuangan. Unit kompetensi audit ini berhubungan erat dengan pengetahuan, skill, dan perilaku kerja yang diperlukan untuk menjalankan program audit yang telah disusun serta mempersiapkan Kertas Kerja Pemeriksaan (KKP).

Berdasarkan SKKNI terdapat beberapa pembagian elemen kompetensi dalam melaksanakan proses audit berbasis informasi keuangan, yaitu:

1. Melaksanakan review pada rencana pengauditan, yaitu: mulai dari review mengidentifikasi fungsi serta tujuan pengauditan, melakukan review lingkup penentuan tugas pengauditan, dan melakukan review dengan mengidentifikasi lingkungan usaha klien.

2. Mengevaluasi Satuan Pengawas Intern (SPI), yaitu melakukan evaluasi untuk memahami pedoman evaluasi sistem internal kontrol, mengevaluasi pengkajian komponen utama (elemen) SPI, mengevaluasi pembuatan dan penyajian laporan setelah mendapatkan hasil atas evaluasi dan mendokumentasikan semua dokumen serta output evaluasi SPI. 
3. Perancangan dan pelaksanaan program pemeriksaan, yaitu program pemeriksaan selesai dirancang, dan mengumpulkan seluruh dokumen bukti-bukti atas pelaksanaan pemeriksaan dan mengidentifikasikannya sesuai dengan program pemeriksaan yang telah disusun.

4. Penyajian kertas kerja pemeriksaan, yaitu menyusun dan menyajikan kertas kerja pemeriksaan, menentukan kepemilikan atas kertas kerja pemeriksaan, menyiapkan dan mengarsipkan atau menyimpan kertas kerja pemeriksaan, dan auditor melakukan penyajian perancangan laporan.

5. Laporan audit disiapkan, yaitu meringkas temuan, membuat daftar ayat jurnal penyesuaian atau jurnal reklasifikasi atas temuan pemeriksaan dan menyusun laporan pemeriksaan sesuai dengan standar pemeriksaan.

\section{METODE PENELITIAN Data Penelitian}

Data sekunder merupakan data yang bersumber dari sistem informasi mahasiswa berupa hasil evaluasi final pada mata kuliah audit. Data inilah yang akan dianalisa di penelitian ini.

\section{Populasi}

Jumlah populasi sebanyak 52 orang mahasiswa semester empat dari kelas A dan B. Rinciannya yaitu 27 orang kelas A dan 25 orang kelas B.

\section{Variabel Penelitian}

Dalam penelitian ini variable yang digunakan hanya satu variabel yang dilihat dari kemampuan atau hasil evaluasi nilai akhir mahasiswa semester 4 kelas A 27 orang mahasiswa dan kelas B 25 orang mahasiswa.

\section{Alat Uji}

Alat uji untuk menguji hipotesis penelitian ini menggunakan uji beda Independent Sample Ttest. menggunakan uji beda Independent Sample T-test digunakan apabila memenuhi kriteria yang disyaratkan dalam statistik parametrik. Apabila hasil uji normalitas menunjukkan bahwa data tidak normal maka uji beda non-parametrik Mann-Whitney akan menjadi alternatif. Uji beda dibutuhkan untuk membandingkan hasil evaluasi dalam mempelajari mata kuliah audit.

\section{HASIL DAN PEMBAHASAN Analisis Deskriptif}

Penelitian yang berhubungan dengan analisis hasil belajar mata kuliah audit ini dilakukan demi mendapatkan bukti tentang kemampuan mahasiswa dalam mata kuliah audit. Penelitian ini akan membuka tabir apakah kelas A dan B terdapat perbedaan berdasarkan hasil evaluasi yang telah dilaksanakan oleh dosen pengampu di masing-masing kelas. Hasil uji deskriptif disajikan dalam Tabel 1.

Tabel 1. Hasil Uji Deskriptif

\begin{tabular}{cccccc}
\hline No & Kelas & Mean & Min & Max & Median \\
\hline 1 & A & 72,14 & 70 & 100 & 70 \\
2 & B & 73,33 & 70 & 100 & 70 \\
\hline
\end{tabular}

Sumber: Output SPSS

Berdasarkan Tabel 1, dapat dijelaskan rata-rata nilai akhir audit pada kelas A adalah 72,1 yang lebih rendah jika dibandingkan dengan nilai akhir di kelas B yaitu 73,3. Maka dapat disimpulkan bahwa nilai audit secara ratarata yang tertinggi menjadi milik mahasiswa kelas B, sebaliknya nilai rata-rata audit di kelas A lebih berfluktuasi yang menyebabkan secara rata-rata menjadi lebih rendah.

\section{Uji Normalitas}

Tujuan dilakukannya uji normalitas yaitu untuk menentukan apakah data yang telah ditabulasi memiliki distribusi data yang normal atau tidak normal. Ketentuan uji normaliatas ini akan mempengaruhi uji hipotesis yang akan digunakan nantinya. Dalam penelitian ini uji normalitas menggunakan Kolmogorov-Smirnov dan alpha 5persen. Output SPSS untuk uji normalitas disajikan di Tabel 2.

Tabel 2. Hasil Uji Normalitas KolmogorovSmirnov

\begin{tabular}{clcc}
\hline No & \multicolumn{1}{c}{ Variabel } & Sig & Keterangan \\
\hline 1 & $\begin{array}{l}\text { Nilai Akhir Audit } \\
\text { Kelas A }\end{array}$ & 0,000 & Tidak Normal \\
2 & $\begin{array}{l}\text { Nilai Akhir Audit } \\
\text { Kelas B }\end{array}$ & 0,000 & Tidak Normal \\
\hline
\end{tabular}

Sumber: Output SPSS

Berdasarkan Tabel 2 dapat dilihat bahwa output SPSS untuk uji normalitas menunjukkan sig sebesar 0,0 lebih kecil dari alpha 5 persen. Tentu hasil ini memberikan jawaban bagi peneliti bahwa data yang telah ditabulasi ternyata memiliki distribusi yang tidak normal. Baik data kelas A maupun data di kelas B. Hasil ini akan memperkuat peneliti untuk menggunakan alternatif pengujian hipotesis menggunakan uji Mann-Whitney yang merupakan salah satu alat uji dalam statistik nonparametrik. 


\section{Uji Hipotesis}

Uji hipotesis dalam penelitian ini ditindaklanjuti dengan melakukan pengujian atas data berdasarkan variabel penelitian. Tujuannya ialah untuk mengetahui apakah hasil evaluasi, kemampuan dan keilmuan mahasiswa di bidang audit antara kelas A dengan kelas B terdapat perbedaan atau tidak.

Setelah dilakukan pengujian uji beda dengan SPSS diperoleh output pengujian. Output pengujian disajikan pada Tabel 3.

Tabel 3. Hasil Uji Beda Mann-Whitney

\begin{tabular}{|c|c|c|c|}
\hline No & Variabel Penelitian & Sig & Keputusan \\
\hline 1 & $\begin{array}{l}\text { Evaluasi Hasil } \\
\text { Belajar Mata Kuliah } \\
\text { Audit }\end{array}$ & 0,348 & $\begin{array}{c}\text { Tidak } \\
\text { berbeda }\end{array}$ \\
\hline
\end{tabular}

Sumber: Output SPSS

Berdasarkan Tabel 3, output SPSS atas uji beda statistik nonparametrik Mann Whitney dengan skor sig sebesar 34,8 persen. Angka sig sebesar 34,8 persen tentu lebih besar jika dibandingkan dengan nilai alpha sebesar 5 persen. Dengan demikian, telah jelas bahwa berdasarkan evaluasi penilaian audit antara kelas A dan kelas B mahasiswa Prodi D4 Akuntansi Keuangan Publik Politeknik Negeri Bengkalis, tidak ditemukan adanya perbedaan. Ini membuktikan bahwa metode pengajaran yang telah diterapkan dalam proses perkuliahan telah meningkatkan kemampuan dan keilmuan mahasiswa di bidang audit baik di kelas A maupun di kelas B. Bahkan setelah dilakukan evaluasi atas nilai akhir mahasiswa, hasil penelitian tidak menemukan perbedaan signifikan. Proses perkuliahan atau transfer ilmu yang baik meskipun di kelas yang berbeda, akan berdampak bagi peningkatan ilmu dan kompetensi mahasiswa dalam mengaudit laporan keuangan sebuah perusahaan.

Hasil penelitian juga memperlihatkan bahwa mahasiswa telah memiliki elemen kompentensi yang diperlukan dalam proses audit berbasis informasi keuangan. Mahasiswa mampu melaksanakan review pada rencana pengauditan, yaitu mulai dari review mengidentifikasi fungsi serta tujuan pengauditan, melakukan review lingkup penentuan tugas pengauditan, dan melakukan review dengan mengidentifikasi lingkungan usaha klien. Mahasiwa mampu mengevaluasi internal kontrol, yaitu melakukan evaluasi untuk memahami pedoman evaluasi sistem internal kontrol, mengevaluasi pengkajian komponen utama (elemen) internal kontrol, mengevaluasi pembuatan dan penyajian laporan setelah mendapatkan hasil atas evaluasi dan mendokumentasikan semua dokumen serta output evaluasi internal kontrol. Mahasiswa mampu menyusun perancangan dan pelaksanaan program pemeriksaan, yaitu program pemeriksaan selesai dirancang, dan mengumpulkan seluruh dokumen bukti-bukti atas pelaksanaan pemeriksaan dan mengidentifikasikannya sesuai dengan program pemeriksaan yang telah disusun. Mahasiswa mampu menyajikan kertas kerja pemeriksaan, yaitu menyusun dan menyajikan kertas kerja pemeriksaan, menentukan kepemilikan atas kertas kerja pemeriksaan, menyiapkan dan mengarsipkan atau menyimpan kertas kerja pemeriksaan, dan auditor melakukan penyajian perancangan laporan. Bahkan mahasiswa mampu menyiapkan laporan audit, yaitu meringkas temuan, membuat daftar ayat jurnal penyesuaian atau jurnal reklasifikasi atas temuan pemeriksaan dan menyusun laporan pemeriksaan sesuai dengan standar pemeriksaan.

Hasil penelitian tentang mata kuliah audit ini menguatkan hasil penelitian yang dilaksanakan sebelumnya oleh Suharyono dan Widodo (2017). Hasil penelitannya menyatakan bahwa hasil belajar mahasiswa tidak ditemukan perbedaan meskipun berbeda dosen yang mengajarkannya. Persamaan dengan penelitian yang telah ada diteliti oleh peneliti sebelumnya, tidak ditemukannya beda antara kompetensi yang diperoleh mahasiswa kelas A dan B menunjukkan bahwa responden telah mampu mengadopsi pengetahuan tentang audit dengan baik sesuai dengan unit kompetensi yang ditetapkan dalam SKKNI. Urgensi pendidikan dengan mengacu kepada SKKNI telah menyadarkan kita tentang pentingnya penyesuaian kurikulum dan silabus untuk mengingkatkan kompetensi lulusan agar mampu berkarir sesuai kompetensinya di industri atau dunia kerja maupun di dunia usaha.

\section{KESIMPULAN DAN SARAN}

Tujuan penelitian adalah untuk membandingkan hasil belajar dan kompetensi mahasiswa dan kinerja usaha belajar pada mata kuliah audit selama satu semester. Seluruh mahasiswa yang telah mengambil mata kuliah audit dijadikan populasi sekaligus sampel dalam penelitian untuk meyakinkan bahwa hasil yang diperoleh dalam penelitian akan mewakili keseluruhan mahasiswa tanpa terkecuali. Penelitian ini akan memastikan kembali tentang 
ada atau tidaknya perbedaan ilmu dan kompetensi mahasiswa dalam mata kuliah audit antara kelas A dan kelas B.

Berdasarkan output SPSS atas uji beda statistik nonparametrik Mann Whitney diperoleh hasil sig sebesar 34,8persen. Angka sig sebesar 34,8persen tentu lebih besar jika dibandingkan dengan nilai alpha sebesar 5persen. Dengan demikian, telah jelas bahwa berdasarkan evaluasi hasil belajar mata kuliah audit antara kelas A dan kelas B mahasiswa, tidak ditemukan adanya perbedaan. Ini membuktikan bahwa metode pengajaran yang telah diterapkan dalam proses perkuliahan telah meningkatkan kemampuan dan keilmuan mahasiswa di bidang audit baik di kelas A maupun dikelas B. Bahkan setelah dilakukan evaluasi atas nilai akhir mahasiswa, hasil penelitian tidak menemukan perbedaan signifikan. Proses perkuliahan atau transfer ilmu yang baik meskipun di kelas yang berbeda, akan berdampak bagi peningkatan ilmu dan kompetensi mahasiswa dalam mengaudit laporan keuangan sebuah perusahaan.

Setiap penelitian tidak ada yang sempurna dan pasti ditemukan keterbatasan. Keterbatasan yang perlu penyempurnaan yaitu dari aspek kualitatif. Penelitian ini akan sempurna jika dilakukan kombinasi metode untuk mengungkap aspek kualitatif dari kompetensi mahasiswa di bidang audit. Sejauh mana peningkatan sebelum dan setelah mengikuti perkuliahan audit, yang hanya dapat diketahui dengan melakukan wawancara ke seluruh responden yang terpilih.

\section{DAFTAR RUJUKAN}

Anas, M. (2019, October). Penerapan Model Pembelajaran Kooperatif Berbasis Kasus Berpusat Kepada Mahasiswa Pada Mata Kuliah Auditing 1. In Seminar Nasional Manajemen, Ekonomi, Akuntansi (Vol. 1, No. 1, pp. 427-433).

Arens dan Loebbecke. (1997). Auditing Pendekatan Terpadu Buku satu. Edisi Indonesia. Jakarta: Salemba Empat

Elias, Rafik, Z. 2006. "The impact of Professional Commitment and Anticipatory Socialization on Accounting Students' Ethical Orientation", Journal of Business Ethics, 68, pp. 8390.
Hawani, I. P., \& Rahmayani, A. (2016). Pengaruh Pengetahuan Mahasiswa Akuntansi Tentang Pajak Dan Audit Terhadap Minat Berkarir Dibidang Perpajakan Dan Audit. Media Akuntansi Perpajakan, 1(1), 62-74.

Indonesia, K. B. B. (2011). Jakarta. Republik Indonesia.

Jalil, F. Y. (2014). Pengaruh komitmen profesional dan sosialisasi antisipatif mahasiswa audit terhadap perilaku whistleblowing. Esensi: Jurnal Bisnis dan Manajemen, 4(2).

Lubis, H. Z. (2018). Implementasi Problem Based Learning Dalam Upaya Peningkatan Kualitas Pembelajaran Auditing. Kumpulan Jurnal Dosen Universitas Muhammadiyah Sumatera Utara.

Republik Indonesia. Peraturan Menteri Ketenagakerjaan Nomor 2 Tahun 2016 Tentang Sistem Standardisasi Kompetensi Kerja Nasional Indonesia.

Rosnidah, I., Sulistyowati, W. A., \& Yulianto, A. (2018). Dilema Etis pada Calon Auditor: Sebuah Eksperimen. Jurnal Akuntansi Indonesia, 7(2), 35-48.

Sahade, S. (2020). Kemandirian dan Motivasi Belajar Siswa Terhadap Prestasi Belajar Program Keahlian Akuntansi Di SMK Negeri 1 Sidenreng Rappang. JEKPEND: Jurnal Ekonomi dan Pendidikan,3(2), 21-28.

Suharyono, S., \& Mule, Y. A. (2019). Comparative Analysis of Students Learning Achievement in The Advanced Public Sector Accounting. Jurnal AKSI (Akuntansi dan Sistem Informasi), 4(2).

Suharyono, S. (2019). Pengaruh Myob Test Clinic Terhadap Kompetensi Mahasiswa. Jurnal Analisa Akuntansi dan Perpajakan, 2(2).

Suharyono, S., \& Widodo, T. (2017). Analisis Hasil Belajar Mahasiswa dalam Mata Kuliah Komputer Akuntansi. Inovbiz: Jurnal Inovasi Bisnis, 5(1), 29-35. 
Suharyono, Evaluasi Pembelajaran Mata Kuliah Audit... $\mid 55$

Wibowo, E. (2011). Analisis Pembelajaran Mata

Auditor Judgment). MAKSIMUM, 1(2).

Kuliah Auditing (Kompentensi Dalam 